\title{
Carbon and greenhouse gas balances in an age sequence of temperate pine plantations
}

\author{
M. Peichl ${ }^{1,2}$, A. M. Arain ${ }^{2}$, T. R. Moore ${ }^{3}$, J. J. Brodeur ${ }^{2}$, M. Khomik ${ }^{2}$, S. Ullah ${ }^{4}$, N. Restrepo-Coupé ${ }^{5}$, J. McLaren², \\ and M. R. Pejam 6 \\ ${ }^{1}$ Department of Forest Ecology and Management, Swedish University of Agricultural Sciences, Umeå, Sweden \\ ${ }^{2}$ McMaster Centre for Climate Change and School of Geography \& Earth Sciences, McMaster University, \\ Hamilton, ON, Canada \\ ${ }^{3}$ Department of Geography and Global Environmental \& Climate Change Centre, McGill University, \\ Montreal, QC, Canada \\ ${ }^{4}$ School of Physical and Geographical Sciences, Keele University, Staffordshire, UK \\ ${ }^{5}$ University of Technology Sydney, Sydney, Australia \\ ${ }^{6}$ Upper Thames River Conservation Authority, London, ON, Canada
}

Correspondence to: M. Peichl (matthias.peichl@slu.se)

Received: 25 April 2014 - Published in Biogeosciences Discuss.: 5 June 2014

Revised: 29 August 2014 - Accepted: 31 August 2014 - Published: 7 October 2014

\begin{abstract}
This study investigated differences in the magnitude and partitioning of the carbon $(\mathrm{C})$ and greenhouse gas (GHG) balances in an age sequence of four white pine (Pinus strobus L.) afforestation stands (7, 20, 35 and 70 years old as of 2009) in southern Ontario, Canada. The 4-year (20042008) mean annual carbon dioxide $\left(\mathrm{CO}_{2}\right)$ exchanges, based on biometric and eddy covariance data, were combined with the 2-year means of static chamber measurements of methane $\left(\mathrm{CH}_{4}\right)$ and nitrous oxide $\left(\mathrm{N}_{2} \mathrm{O}\right)$ fluxes (2006-2007) and dissolved organic carbon (DOC) export below $1 \mathrm{~m}$ soil depth (2004-2005). The total ecosystem $C$ pool increased with age from 46 to $197 \mathrm{t} \mathrm{Cha}^{-1}$ across the four stands. Rates of organic matter cycling (i.e. litterfall and decomposition) were similar among the three older stands. In contrast, considerable differences related to stand age and site quality were observed in the magnitude and partitioning of individual $\mathrm{CO}_{2}$ fluxes, showing a peak in production and respiration rates in the middle-age (20-year-old) stand growing on fertile postagricultural soil. The DOC export accounted for $10 \%$ of net ecosystem production (NEP) at the 7-year-old stand but $<2 \%$ at the three older stands. The GHG balance from the combined exchanges of $\mathrm{CO}_{2}, \mathrm{CH}_{4}$ and $\mathrm{N}_{2} \mathrm{O}$ was 2.6, 21.6, 13.5 and $4.8 \mathrm{t} \mathrm{CO}_{2}$ equivalent $\mathrm{ha}^{-1}$ year $^{-1}$ for the 7-, 20-, 35- and 70-year-old stands, respectively. The maximum annual contribution from the combined exchanges of $\mathrm{CH}_{4}$ and
\end{abstract}

$\mathrm{N}_{2} \mathrm{O}$ to the GHG balance was 13 and $8 \%$ in the 7- and 70year-old stands, respectively, but $<1 \%$ in the two highly productive middle-age (20- and 35-year-old) stands. Averaged over the entire age sequence, the $\mathrm{CO}_{2}$ exchange was the main driver of the GHG balance in these forests. The cumulative $\mathrm{CO}_{2}$ sequestration over the 70 years was estimated at $129 \mathrm{tC}^{\mathrm{C}}$ and $297 \mathrm{t} \mathrm{C} \mathrm{ha}^{-1}$ year $^{-1}$ for stands growing on low- and high-productivity sites, respectively. This study highlights the importance of accounting for age and site quality effects on forest $\mathrm{C}$ and $\mathrm{GHG}$ balances. It further demonstrates a large potential for net $\mathrm{C}$ sequestration and climate benefits gained through afforestation of marginal agricultural and fallow lands in temperate regions.

\section{Introduction}

The global temperature increase over the past century has been attributed to increasing concentrations of atmospheric greenhouse gases (GHGs) such as carbon dioxide $\left(\mathrm{CO}_{2}\right)$, methane $\left(\mathrm{CH}_{4}\right)$ and nitrous oxide $\left(\mathrm{N}_{2} \mathrm{O}\right)$, among others, coupled with human activities (e.g. fossil fuel burning, deforestation) and natural processes in terrestrial ecosystems (Houghton et al., 1998; IPCC, 2013; Schimel, 1995; Schulze et al., 2009). Much effort has since been put into mitigating 
the atmospheric GHG concentrations through sequestration and/or their emission reduction strategies through land use management activities (Montzka et al., 2011; Nabuurs et al., 2007; Smith et al., 2008).

Among land use types, forest ecosystems have the strongest carbon (C) sink potential and provide stocks of 100 to $160 \mathrm{GtC}$ in biomass and soil in temperate regions alone (Dixon et al., 1994; Goodale et al., 2002; Pan et al., 2011; Reich, 2011). Moreover, much of the current $\mathrm{CO}_{2}$ sink strength of the Northern Hemisphere has been attributed to re-growth and afforestation of former agricultural land in the US and Canada (Pan et al., 2011; Reich, 2011). Therefore, further afforestation of former agricultural lands of low productivity has been proposed to help offset the increasing concentration of atmospheric $\mathrm{CO}_{2}$ (Bárcena et al., 2014; Brown, 2002; Goodale et al., 2002; Nabuurs et al., 2007; Niu and Duiker, 2006).

Afforestation of former agricultural lands and associated changes in land management practices, however, do not only result in accumulation of $\mathrm{C}$ into biomass, but may also alter soil and micro-climatic conditions. Tree root development, litterfall, canopy shading and cessation of $\mathrm{N}$-fertilizer application, for instance, may trigger changes in physical, biogeochemical and hydrological properties of the soil, which may affect the net exchange of $\mathrm{CH}_{4}$ and $\mathrm{N}_{2} \mathrm{O}$ (Ball et al., 2007; Christiansen and Gundersen, 2011; Christiansen et al., 2012; Gundersen et al., 2012; Peichl et al., 2010b; Priemé et al., 1997; Smith et al., 2003; Ullah and Moore, 2011), as well as the cycling of dissolved organic carbon (DOC) (Camino-Serrano et al., 2014; Gielen et al., 2011; Peichl et al., 2007; Rosenqvist et al., 2010). Such alterations might modify the net ecosystem production (NEP) and the GHG balance (Luyssaert et al., 2010, 2012; Schulze et al., 2009, 2010). Moreover, since $\mathrm{CH}_{4}$ and $\mathrm{N}_{2} \mathrm{O}$ have a 34- and 298times-greater global warming potential (GWP) relative to $\mathrm{CO}_{2}$ on molar basis over 100 years when including carbonclimate feedbacks (IPCC, 2013), afforestation effects on the exchange of these GHGs might be even more pronounced with respect to the net radiative forcing (Inatomi et al., 2010; Montzka et al., 2011; Schulze et al., 2009).

The impacts of afforestation on ecosystem $\mathrm{C}$ pools and GHG fluxes may also change with stand age over time, including short-term ( $<10$ years; Bjarnadottir et al., 2009; Don et al., 2009; Zona et al., 2013), intermediate ( $\sim 10$ to 50 years; Ball et al., 2007; Christiansen and Gundersen, 2011) and long-term ( $>50$ years; Coursolle et al., 2012; Hiltbrunner et al., 2012; Priemé et al., 1997) effects. In addition, site quality (which includes all environmental factors influencing tree growth and thus biomass production and decomposition) might exert a strong control on the forest $\mathrm{CO}_{2}$ exchange and $\mathrm{C}$ flux partitioning (Fernández-Martínez et al., 2014; McLeod and Running, 1988; Peichl et al., 2010a; Vanninen et al., 1996; Vicca et al., 2012). Changes in the magnitude of the $\mathrm{CO}_{2}$ exchange subsequently have implications for the relative contribution of the individual $\mathrm{C}$ and GHG fluxes to the total C and GHG budgets following afforestation. Thus, knowledge of the changes over the entire lifespan of the afforested stand and of the initial site conditions and quality are required to understand the overall implications of such land use practices for the C and GHG balances at ecosystem and regional scales.

To date, few attempts have been made to estimate the full forest $\mathrm{C}$ and $\mathrm{GHG}$ balance by including measurements of all relevant fluxes of $\mathrm{CO}_{2}, \mathrm{CH}_{4}, \mathrm{~N}_{2} \mathrm{O}$ and DOC. Ball et al. (2007) estimated that the combined contribution of $\mathrm{CH}_{4}$ and $\mathrm{N}_{2} \mathrm{O}$ to the total GHG balance was $6-7 \%$ in maturing (20-30 years old) coniferous forests. In a young poplar plantation, the contribution of $\mathrm{CH}_{4}$ and $\mathrm{N}_{2} \mathrm{O}$ was reported to account for $50 \%$ of the GHG balance (Zona et al., 2013). Using a process-based model, Inatomi et al. (2010) estimated the GHG balance of a 50-year-old temperate broadleaved forest at $10 \mathrm{t} \mathrm{CO}_{2} \mathrm{ha}^{-1}$ year $^{-1}$ by including all three GHGs $\left(\mathrm{CO}_{2}\right.$, $\left.\mathrm{CH}_{4}, \mathrm{~N}_{2} \mathrm{O}\right)$, with a small $(<2 \%)$ contribution from $\mathrm{CH}_{4}$ and $\mathrm{N}_{2} \mathrm{O}$ fluxes. On a larger regional scale, Tian et al. (2010) suggested in their model study that emissions of $\mathrm{CH}_{4}$ and $\mathrm{N}_{2} \mathrm{O}$ from terrestrial ecosystems may offset about two-thirds of the land $\mathrm{CO}_{2}$ sink over the North American continent. However, DOC fluxes were not included in these studies. Gielen et al. (2011) reported that the lateral export of DOC accounted for $11 \%$ of the NEP in forests. Thus, these previous studies indicate substantial contributions from non- $\mathrm{CO}_{2}$ carbon and GHG fluxes and the need for including these exchanges when estimating and/or modelling full forest $\mathrm{C}$ and GHG budgets.

In this study, we estimated the C and GHG balances of four afforested pine stands ranging from 7 to 70 years of age. The main objectives were (i) to determine the effects of stand age and site quality on the forest $\mathrm{C}$ and GHG balances and (ii) to investigate the contribution of non- $\mathrm{CO}_{2}$ fluxes (i.e. $\mathrm{CH}_{4}$, $\mathrm{N}_{2} \mathrm{O}$ and DOC) to the forest $\mathrm{C}$ and GHG balances.

\section{Material and methods}

\subsection{Study sites}

This study was conducted in four eastern white pine (Pinus strobus L.) forests, which are part of the Turkey Point Flux Station located on the north shore of Lake Erie in southern Ontario, Canada $\left(42^{\circ} 71^{\prime} \mathrm{N}, 80^{\circ} 36^{\prime} \mathrm{W}\right)$. The region has a temperate climate with a 30-year mean annual temperature of $8.0^{\circ} \mathrm{C}$ and an annual precipitation of $1036 \mathrm{~mm}$ (Environment Canada norms from 1981 to 2010 at Delhi, Ontario). The two older forests were planted in 1939 (TP39; 70 years old in 2009) and 1974 (TP74; 35 years old in 2009) on cleared oak-savannah land, while the two younger stands were established on former agricultural lands in 1989 (TP89; 20 years old in 2009) and in 2002 (TP02; 7 years old in 2009). At the oldest site, TP39, a moderate thinning was carried out in 1983. Although all four stands grow on generally 
Table 1. Site characteristics of the four Turkey Point pine forest stands (adopted from Peichl et al., 2010a).

\begin{tabular}{|c|c|c|c|c|}
\hline Site code & TP02 & TP89 & TP74 & TP39 \\
\hline Planting year & 2002 & 1989 & 1974 & 1939 \\
\hline Age in 2009 (years) & 7 & 20 & 35 & 70 \\
\hline Tree height $(\mathrm{m})^{\mathrm{a}}$ & $3.6 \pm 0.4$ & $13.4 \pm 0.9$ & $13.5 \pm 0.7$ & $22.5 \pm 1.4$ \\
\hline Tree diameter at breast height $(\mathrm{cm})^{\mathrm{a}}$ & $5.3 \pm 0.9$ & $18.2 \pm 0.6$ & $16.7 \pm 0.3$ & $35.9 \pm 5.9$ \\
\hline Stem density $\left(\text { stems ha }{ }^{-1}\right)^{\mathrm{a}}$ & $1683 \pm 189$ & $1317 \pm 251$ & $1608 \pm 138$ & $421 \pm 166$ \\
\hline Leaf area index $\left(\mathrm{m}^{2} \mathrm{~m}^{-2}\right)^{\mathrm{b}}$ & 1.5 & 12.8 & 5.6 & 8.0 \\
\hline Site index $\left(\mathrm{SI}_{25}\right)^{\mathrm{c}}$ & 60 & 55 & 28 & 26 \\
\hline Forest floor $\mathrm{C}: \mathrm{N}$ ratio & N.A. & 16.1 & 24.5 & 17.4 \\
\hline Mineral soil $\mathrm{C}: \mathrm{N}$ ratio $(0-10 \mathrm{~cm})$ & 11.4 & 14.2 & 19.4 & 15.4 \\
\hline Soil N $(0-10 \mathrm{~cm})\left(\mathrm{g} \mathrm{m}^{-2}\right)$ & 86 & 94 & 67 & 67 \\
\hline Soil C $(0-55 \mathrm{~cm})\left(\mathrm{g} \mathrm{m}^{-2}\right)$ & 3720 & 3390 & 3670 & 3670 \\
\hline Soil $\mathrm{pH}_{(\mathrm{CaCl})}(0-10 \mathrm{~cm})$ & 6.3 & 4.3 & 3.7 & 4.1 \\
\hline Mean water table depth (m) & $2-3.5$ & $0.5-2$ & $6-7$ & $6-7$ \\
\hline
\end{tabular}

a in 2008, ${ }^{\text {b }}$ Chen et al. (2006), ${ }^{\mathrm{c}}$ Peichl et al. (2010a), N.A. stands for not available.

similar sandy and dry soils, the two youngest sites (TP02 and TP89) are characterized by greater site quality compared to the two older sites (Table 1). The higher site quality at the two younger stands might result from post-agricultural remnants of nutrients (e.g. elevated soil nitrogen and $\mathrm{pH}$; see Table 1). In addition, high site productivity at the 20 -yearold site, TP89, is further due to a shallow ground water table that allows trees to have continuous access to water (Peichl et al., 2010a). Each site has a tower instrumented for eddy covariance flux and meteorological measurements. A suite of standard instruments for soil temperature and soil moisture measurements at several depths is also installed at each site. More details of site-specific instrumentation, stand and soil characteristics are given in previous studies (Arain and Restrepo-Coupe, 2005; Khomik et al., 2010; McLaren et al., 2008; Peichl and Arain, 2006; Peichl et al., 2010a).

\subsection{Biometric estimates of $\mathrm{C}$ pools and fluxes}

Above- and belowground $\mathrm{C}$ pools in forest biomass and soil were determined in permanent sample plots established at each site in 2004 following the National Forest Inventory Protocol (NFI, 2003) as described in detail in Peichl and Arain (2006) and Peichl et al. (2010c). Using data from these NFI inventory plots, biomass and detritus pools of canopy and understorey trees, ground vegetation and forest floor (LFH layer) were determined each year in autumn. Forest floor woody debris pools were determined using the line intersect method (Van Wagner, 1968). Soil C and fine root biomass pools were determined from soil coring in 2004. Litterfall was collected using litter traps bi-weekly to seasonally (i.e. every three months) in 2004-2006 and bi-annually in 2007-2008 (once immediately after the peak litterfall period in autumn capturing $\sim 80 \%$ of the annual litterfall and once in spring after the snowmelt) (Peichl et al., 2010c). Forest floor litter decomposition rates were determined over 4 years (from autumn 2004 to autumn 2008) at the three older sites. Litter bags with $1 \mathrm{~mm}$ mesh size were filled with $10 \mathrm{~g}$ of airdried pine needles, and 20 bags were retrieved annually to determine the mass loss.

Net primary production (NPP) was determined from the annual changes in living biomass $\left(\Delta B_{\mathrm{L}}\right)$ and detritus $\left(\Delta B_{\mathrm{D}}\right)$ pools based on annual inventory and litterfall data combined with site-specific allometric biomass equations (Peichl and Arain, 2007) (Eq. 1). Soil respiration $\left(R_{\mathrm{S}}\right)$ was measured from 2004 to 2007 using a LiCor LI-6400 portable chamber system (Khomik et al., 2006, 2009). Soil heterotrophic respiration $\left(\mathrm{RH}_{\mathrm{S}}\right)$ was computed using a site-specific soil respiration model derived from trenched plot respiration data and further partitioned into heterotrophic respiration from mineral soil $\left(\mathrm{RH}_{\mathrm{M}}\right)$ and litter layer $\left(\mathrm{RH}_{\mathrm{LFH}}\right)$ (Eq. 2) (Peichl et al., 2010b, c). Heterotrophic respiration from aboveground woody debris $\left(\mathrm{RH}_{\mathrm{WD}}\right)$ was derived from woody debris decomposition rates (Black et al., 2007; Law et al., 2001) and woody debris pools and added to $\mathrm{RH}_{\mathrm{s}}$ to obtain total heterotrophic respiration (RH) (Eq. 3). Autotrophic root respiration $\left(\mathrm{RA}_{\mathrm{R}}\right)$ was determined from the difference between $\mathrm{R}_{\mathrm{S}}$ and $\mathrm{RH}_{\mathrm{S}}$ (Eq. 4), while autotrophic aboveground canopy respiration $\left(R A_{C}\right)$ was derived by subtracting $R_{R}$ from $R A$ (Eq. 5), with RA being the difference between biometric estimates of NPP and gross primary production (GPP; Peichl et al., 2010c). The biometric estimate of GPP was estimated from NPP assuming that NPP is a constant fraction (47\%) of GPP on the annual scale as suggested for coniferous forests by Waring et al. (1998). 
The biometric estimate of RE was calculated as the sum of the individual respiration terms (Eq. 6).

$$
\begin{aligned}
& \mathrm{NPP}=\Delta B_{\mathrm{L}}+\Delta B_{\mathrm{D}} \\
& \mathrm{RH}_{\mathrm{S}}=\mathrm{RH}_{\mathrm{M}}+\mathrm{RH}_{\mathrm{LFH}} \\
& \mathrm{RH}=\mathrm{RH}_{\mathrm{S}}+\mathrm{RH}_{\mathrm{WD}} \\
& \mathrm{RA}_{\mathrm{R}}=R_{\mathrm{S}}-\mathrm{RH}_{\mathrm{S}} \\
& \mathrm{RA}_{\mathrm{C}}=\mathrm{RA}-\mathrm{RA}_{\mathrm{R}} \\
& \mathrm{RE}=\mathrm{RH}_{\mathrm{S}}+\mathrm{RH}_{\mathrm{WD}}+\mathrm{RA}_{\mathrm{R}}+\mathrm{RA}_{\mathrm{C}}
\end{aligned}
$$

The biometric estimates of individual component fluxes were used to demonstrate their within-ecosystem partitioning, whereas total RE and GPP were further combined with EC-derived estimates on the stand level as described further below (Sect. 2.4).

\subsection{DOC export}

The DOC export as the difference between input via precipitation and soil leaching below $1 \mathrm{~m}$ depth was estimated for the snow-free periods (April-December) of 2004 and 2005. Precipitation was collected in plastic buckets equipped with a funnel on top of meteorological towers at bi-weekly to monthly intervals and analysed for its DOC concentration using a Shimadzu 5050 Analyzer. Soil samples from $1 \mathrm{~m}$ depth were taken to estimate the null-point DOC concentration $\left(\mathrm{DOC}_{\mathrm{np}}\right)$ as an indicator of the potential for DOC concentrations leaching below this depth (Moore et al., 1992). The export of DOC via soil water leaching was calculated by multiplying seasonal water leaching rates with $\mathrm{DOC}_{\mathrm{np}}$ concentration at $1 \mathrm{~m}$ depth. The water leaching rate was estimated as the difference between precipitation and evapotranspiration (based on EC measurements) during the frost-free period, assuming zero run-off at these flat and sandy sites. A more detailed description is provided by Peichl et al. (2007).

\subsection{Measurements of GHG $\left(\mathrm{CO}_{2}, \mathrm{CH}_{4}\right.$ and $\left.\mathrm{N}_{2} \mathrm{O}\right)$ fluxes}

\subsection{1 $\mathrm{CO}_{2}$ fluxes}

Annual GPP, ecosystem respiration (RE) and NEP were estimated from eddy covariance (EC) measurements at all four sites from 2004 to 2008 . Instrument setup and the data processing procedure are described in detail in Arain and Restrepo (2005) and Peichl et al. (2010a). Briefly, a closedpath eddy covariance system (infrared gas analyser (IRGA), model LI-7000, LI-COR Inc.; sonic anemometer model CSAT-3, Campbell Scientific Inc. (CSI); fine-wire thermocouple) was operated at the 70-year-old stand, TP39, while an open-path system (IRGA model LI-7500; LI-COR Inc.; sonic anemometer model CSAT-3, CSI; fine-wire thermocouple) was rotated at bi-weekly to monthly intervals among the three younger sites from 2004 to 2007. In 2008, measurements were terminated at the 20-year-old stand, TP89, while continuous measurements were started at the 35- and 7-year- old (i.e. TP74 and TP02) sites using closed-path EC systems, comprising Li-7000 IRGAs and CSAT3 sonic anemometers. For each of the three younger sites, data from all years were pooled and site-specific models were developed based on parameterization to environmental variables to fill the missing flux data (Peichl et al., 2010a). Since the absolute values for the EC estimates of NEP, GPP and RE differed from their respective biometric estimates, their means from both EC and biometric estimates are presented to obtain a more robust estimate that is constrained by both methods. The mean RE and GPP fluxes therefore do not exactly match the sum of their individual biometric component flux estimates.

\subsection{2 $\mathrm{CH}_{4}$ and $\mathrm{N}_{2} \mathrm{O}$ fluxes}

Fluxes of $\mathrm{CH}_{4}$ and $\mathrm{N}_{2} \mathrm{O}$ were determined at monthly intervals at all four sites from April to December of 2006 and 2007 using the static chambers as described by Peichl et al. (2010b). Briefly, air samples $(20 \mathrm{~mL})$ were withdrawn using syringes at 0,30, 60 and 90 min through a plastic tube inserted into evacuated glass vials $(13 \mathrm{~mL})$ equipped with a grey butyl septum in the field and analyzed within one week for $\mathrm{CH}_{4}$ concentrations using a Shimadzu Mini Gas Chromatograph (GC) (Shimadzu Scientific Instruments, Columbia, ML, USA) equipped with a methanizer and a flame ionization detector (FID) detector and for $\mathrm{N}_{2} \mathrm{O}$ concentrations using a Shimadzu 14-A GC (Shimadzu Scientific Instruments, Columbia, ML, USA) equipped with an electron capture detector (ECD). Fluxes were calculated from the linear increase in gas concentrations over the sampling period. To obtain cumulative sums, fluxes were linearly interpolated and converted to $\mathrm{CO}_{2}$ equivalent $\left(\mathrm{CO}_{2} \mathrm{eq}\right)$ using the GWP (over a 100-year time frame including carbon-climate feedbacks) of 34 and 298 for $\mathrm{CH}_{4}$ and $\mathrm{N}_{2} \mathrm{O}$, respectively (IPCC, 2013). The mean of the 2 measured years was combined with the 4-year mean $\mathrm{C}$ balance (i.e. NEP minus DOC export) in $\mathrm{CO}_{2}$ eq to obtain an estimate of the total GWP. Exchanges of $\mathrm{CH}_{4}, \mathrm{~N}_{2} \mathrm{O}$ and DOC were not estimated during the snowcovered months (January to March), which might have led to underestimation of the total annual exchange. Especially in regions with discontinuous snow cover and frequent freezethaw events, large winter emissions of $\mathrm{N}_{2} \mathrm{O}$ may occur during these periods (Luo et al., 2012; Teepe et al., 2001). However, winter season fluxes of $\mathrm{CH}_{4}, \mathrm{~N}_{2} \mathrm{O}$ and DOC in forests that experience severe winters with continuous snow cover are generally small (Ågren et al., 2007; van Bochove et al., 2000; Yashiro et al., 2006). Since our study sites experience temperatures below freezing and continuous snow cover from December to March, these winter fluxes were assumed to have a negligible effect on the total $\mathrm{C}$ and $\mathrm{GHG}$ balances in our study. 


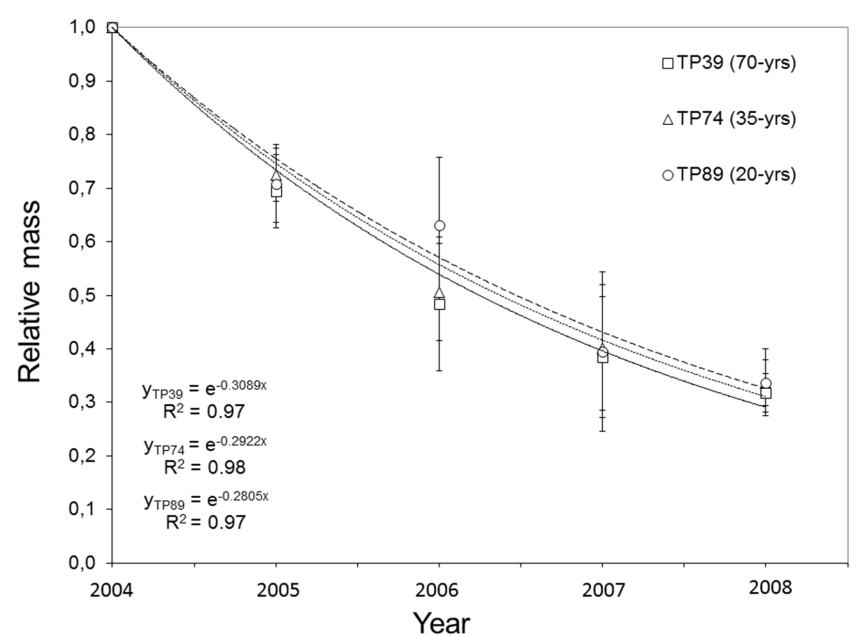

Figure 1. Needle litter decomposition rates over 4 years (20042008) at the three older Turkey Point pine forest sites: TP89, TP74 and TP39 (20, 35 and 70 years old, respectively).

\subsection{Site quality effects on cumulative NEP}

To estimate the total $\mathrm{C}$ sequestration from the cumulative NEP over the entire age sequence, measured annual NEP values from the four sites were linearly interpolated to obtain a 70-year record of annual NEP. Following Peichl et al. (2010a), two scenarios were developed in which NEP values for the four sites were normalized by differences in their site indices (SIs). The SI is a common measure to describe the site quality and is used as a predictor for tree growth in forest stands (e.g. Milner, 1992). In the first "lowproductivity" scenario, it was assumed that all four stands grow on low-quality soils by applying an SI correction on NEP for TP02 and TP89 to match the SI of TP74 and TP39. Conversely, in the second "high-productivity" scenario, NEP at TP74 and TP39 was normalized to match the SI of TP02 and TP89 following the assumption that all four stands grow on high-quality soils.

\section{Results}

\subsection{Forest $\mathrm{C}$ pools and fluxes}

Needle litter decomposition rates did not differ significantly among the three older sites, with the exponential annual decay coefficient $k$ ranging from 0.28 to 0.31 (Fig. 1). The rates of needle litterfall exceeded those of decomposition, resulting in a net accumulation of 3.7, 2.0 and 3.2 $\mathrm{tha}^{-1}$ year $^{-1}$ at the 20-, 35- and 70-year-old stands, respectively (Fig. 2).

The total ecosystem $\mathrm{C}$ pool (including vegetation and soil) increased with age from $46 \mathrm{tCha}^{-1}$ at the youngest site to $197 \mathrm{tC} \mathrm{ha}^{-1}$ at the oldest site (Fig. 3). The largest age-related differences in $\mathrm{C}$ pools among sites occurred in stem and root biomass, whereas the canopy (foliage and branches) $\mathrm{C}$ pool

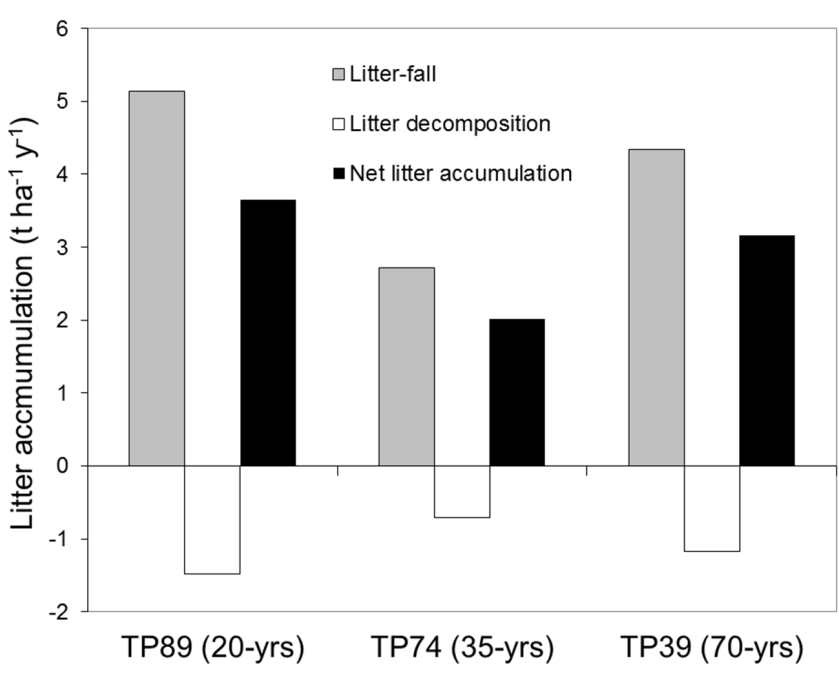

Figure 2. Needle litterfall, decomposition and net accumulation on the forest floor over 4 years (2004-2008) at the three older Turkey Point pine forest sites: TP89, TP74 and TP39.

was similar among the three older stands. The sum of the secondary C pools - such as woody debris, understorey and ground vegetation - was small and similar among the three younger sites (ranging from 1.5 to $2.7 \mathrm{t} \mathrm{Cha}^{-1}$ ) compared to that of the 70-year-old stand $\left(11.3 \mathrm{tC} \mathrm{ha}^{-1}\right)$.

The NPP ranged between $379 \mathrm{~g} \mathrm{C} \mathrm{m}^{-2}$ year $^{-1}$ at the 7year-old stand to $835 \mathrm{~g} \mathrm{C} \mathrm{m}^{-2}$ year $^{-1}$ at the 20 -year-old stand. Age-related differences in RE were mainly driven by changes in RA and RH from aboveground biomass and litter, whereas belowground root respiration and soil RH were similar among the four stands.

\subsection{Forest $\mathrm{C}$ balance}

The mean NEP over the 4 years was 70, 590, 280 and $130 \mathrm{~g}$ $\mathrm{C} \mathrm{m}^{-2}$ year $^{-1}$ at the 7-, 20-, 35- and 70-year-old stands, respectively (Fig. 3). The 2-year mean DOC export decreased with stand age from $7 \mathrm{~g} \mathrm{C} \mathrm{m}^{-2}$ year $^{-1}$ at the 7 -year-old stand to 4,3 and $2 \mathrm{~g} \mathrm{C} \mathrm{m}^{-2}$ year $^{-1}$ at the 20-, 35- and 70-yearold stands, respectively (Fig. 3). The relative contribution of the net DOC export (i.e. the difference between DOC input via precipitation and DOC export at $1 \mathrm{~m}$ depth) to NEP decreased from $10 \%$ at the 7-year-old stand to less than 1-2\% at the three older stands (Fig. 4a).

\subsection{Forest GHG balance}

Across the four stands, the combined $\mathrm{N}_{2} \mathrm{O}$ and $\mathrm{CH}_{4}$ flux ranged from -0.4 to $0.1 \mathrm{t} \mathrm{CO}_{2}$ eq ha $^{-1}$ year $^{-1}$ during the 2 measurement years (Fig. 3). The net GHG balance derived from the mean $\mathrm{C}$ balance and the combined $\mathrm{N}_{2} \mathrm{O}$ and $\mathrm{CH}_{4}$ flux was $-2.6,-21.6,-13.5$ and $-4.8 \mathrm{t} \mathrm{CO}_{2}$ eq ha ${ }^{-1}$ year $^{-1}$ at the 7-, 20-, 35- and 70-year-old stands, respectively (Fig. 3). The combined relative contribution of 

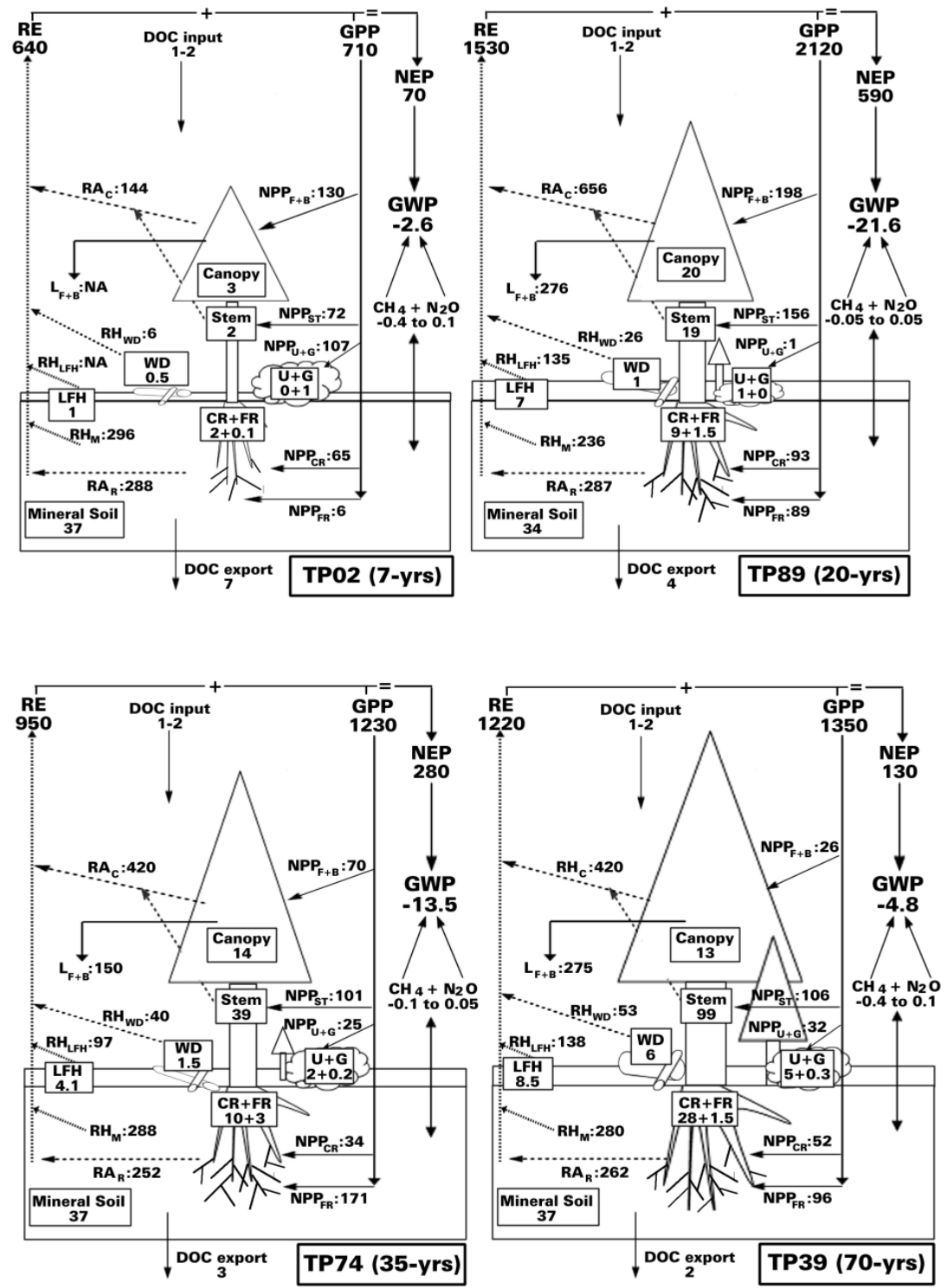

Figure 3. Ecosystem carbon (C) pools (square boxes; $t \mathrm{C} \mathrm{ha}^{-1}$ ), $\mathrm{C}$ fluxes (gross and net primary production (GPP, NPP), litter-fall and DOC flux = solid arrows, ecosystem respiration (RE) fluxes = dotted arrows; $\mathrm{g} \mathrm{C} \mathrm{m}^{-2}$ year $\left.{ }^{-1}\right), \mathrm{CH} 4$ and $\mathrm{N} 2 \mathrm{O}$ fluxes $\left(t \mathrm{CO}_{2}\right.$ eq ha $^{-1}$ year $\left.^{-1}\right) \mathrm{and}$ GHG balance expressed as global warming potential (GWP; $t \mathrm{CO}_{2}$ eq ha $^{-1}$ year ${ }^{-1}$ ) at the four Turkey Point pine forest sites, TP02, TP89, TP74 and TP39. Abbreviations: $\mathrm{C}=$ canopy; $\mathrm{F}=$ foliage; $\mathrm{B}=$ branches; $\mathrm{ST}=$ stem; $\mathrm{LFH}=$ forest floor; $\mathrm{WD}=$ woody debris; $\mathrm{CR}=$ coarse roots; $\mathrm{FR}=$ fine roots; $\mathrm{U}=$ understorey; $\mathrm{G}=$ ground vegetation; $\mathrm{M}=$ mineral soil; $\mathrm{R}=$ roots; $\mathrm{RH}=$ heterotrophic respiration; $\mathrm{RA}=$ autotrophic respiration; $\mathrm{L}=$ litter-fall; $\mathrm{DOC}=$ dissolved organic carbon; $\mathrm{NA}=$ not available

$\mathrm{CH}_{4}$ and $\mathrm{N}_{2} \mathrm{O}$ to the $\mathrm{GHG}$ balance ranged from $<1 \%$ at the 20 - and 35 -year-old stands to 13 and $8 \%$ at the 7 - and 70 year-old stands, respectively (Fig. 4b).

\subsection{Site quality effect on the cumulative NEP}

Over the initial 70 years following afforestation, the cumulative $\mathrm{CO}_{2}$ sequestration ranged from $129 \mathrm{t} \mathrm{Cha}^{-1}$ for a lowproductivity (i.e. site index $=26$ ) forest to $297 \mathrm{t} \mathrm{Cha}^{-1}$ for highly productive (i.e. site index $=60$ ) forest (Fig. 5). The $\mathrm{C}$ compensation point (i.e. the timing when net $\mathrm{CO}_{2}$ accu- mulation becomes positive) was reached about 10 years after plantation establishment in both scenarios.

\section{Discussion}

\subsection{The forest $\mathrm{C}$ balance across stand age and site quality}

Following afforestation of low-productivity agricultural and other marginal land, the balance of needle litter production 


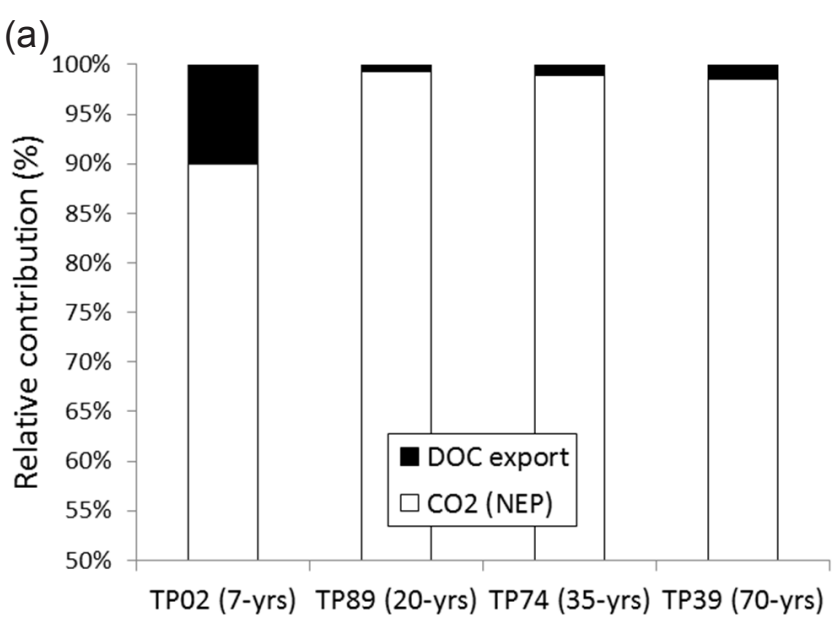

(b)

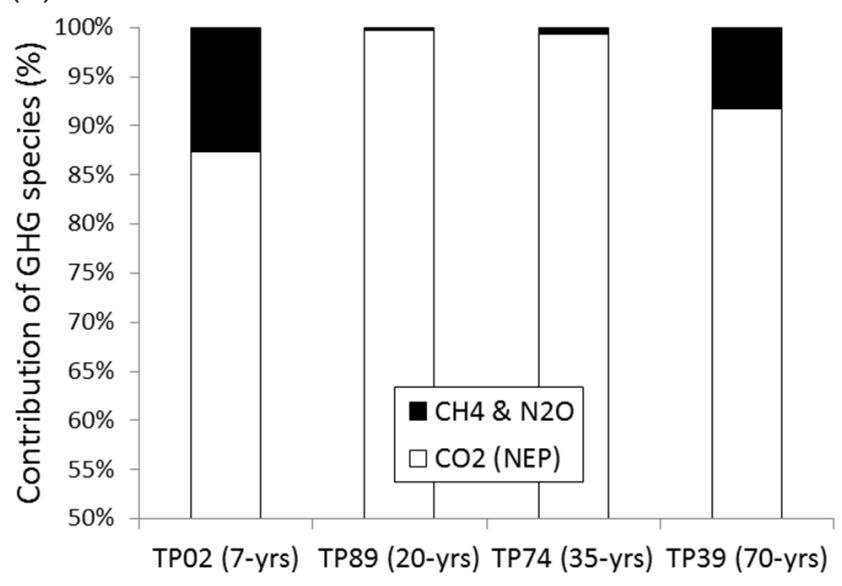

Figure 4. (a) Relative contributions of the DOC export (below $1 \mathrm{~m}$ depth) and NEP to the total $\mathrm{C}$ balance and (b) relative contribution of the $\mathrm{CO}_{2}$ exchange and the combined $\mathrm{CH}_{4}$ and $\mathrm{N}_{2} \mathrm{O}$ exchange to the GHG balance at the four Turkey Point pine forest sites: TP02, TP74, TP89 and TP39.

and decomposition is a major determinant of the accumulation and partitioning of organic matter into soil organic carbon accumulation and losses due to heterotrophic respiration (Yang et al., 2011). In our study, we did not find any agerelated differences for organic matter turnover when comparing litterfall and decomposition rates among the three older sites. Decomposition rates were within the range of those previously reported for other Canadian coniferous forests (Moore et al., 1999; Trofymow et al., 2002) and appeared to be unaffected by either stand age or site quality. In contrast, age-related differences in the litterfall rates were apparent when comparing the 35- and 70-year-old stands, with the latter one having higher rates (but similar SI values). However, across the entire age sequence, an age effect on litterfall previously observed in other studies (e.g. Law et al., 2001) was likely masked by the high litterfall rates at our 20-yearold high-productivity site.

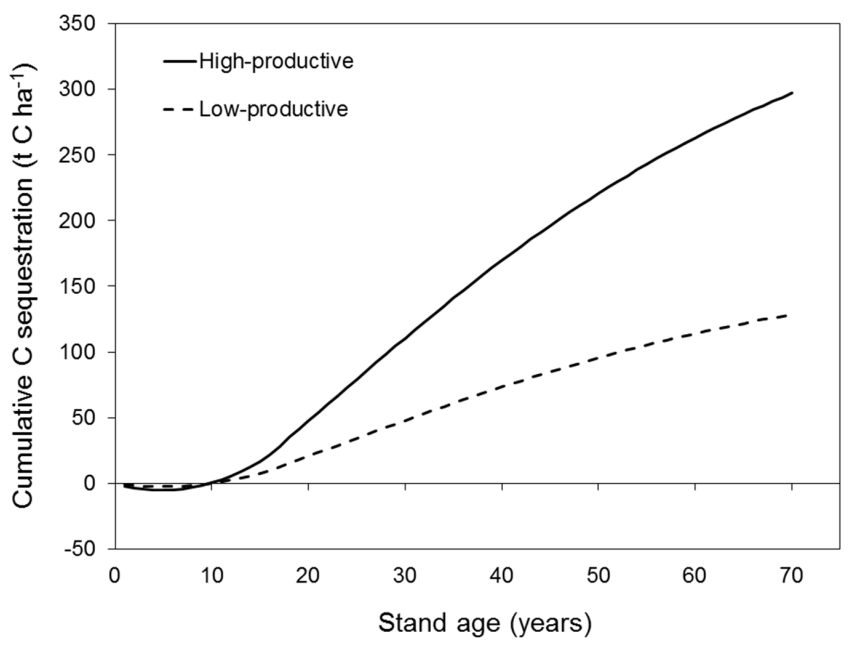

Figure 5. Cumulative $C$ sequestration assuming high (site in$\operatorname{dex}=60$; solid line) and low (site index $=26$; dashed line) site quality for all four Turkey Point pine stands.

In contrast to the small differences in organic matter turnover, we observed manifold changes in the magnitudes and partitioning of the $\mathrm{C}$ fluxes among the four stands. These changes were primarily driven by the differences in aboveground biomass and flux components. It is further noteworthy that the changes in individual biomass pools did not always reflect the changes in their associated in- and/or outgoing $\mathrm{C}$ fluxes. For instance, a small difference in $\mathrm{RA}_{\mathrm{R}}$ despite manifold changes in fine root biomass among the four stands was observed. This might have resulted from (i) a temporal mismatch in measurements (fine root biomass was determined in 2004 when seedling trees at the youngest site were only 2 years old, whereas root respiration was also estimated during the subsequent years (2004-2008) of rapid tree seedling and herbaceous ground cover development), (ii) a masking effect from greater understorey and/or groundcover root respiration at the youngest and oldest stands and (iii) contrasting patterns in the allocation of assimilates from the canopy to the roots in the high- vs. low-productivity stands (Vicca et al., 2012). Thus, this observation indicates some limitations to inferring $\mathrm{C}$ fluxes solely from the magnitude of the biomass pools.

Although stand age and site quality were not fully replicated among the four sites, we suggest that, given the similar climatic conditions, most of the observed differences in the $\mathrm{C}$ balances might be explained by either one or both factors. Age-related differences become most evident when comparing the two younger (both having a similar high SI) and the two older sites (both having a similar low SI), respectively. In both cases, the comparison suggests greater NEP and NPP in the middle-age stands ( 20 and 35 years old) compared to the young and mature stand. An additional effect of site quality may explain the large difference in NEP and NPP between the two middle-age stands, with considerably higher values 
noted at the 20-year-old stand characterized by a higher (i.e. double) SI value. In contrast to NEP and NPP, mean GPP and RE increased from the 7- to the 20-year-old stand as well as from the 35- to 70-year-old stand. This indicates that GPP and RE have not yet reached their maxima in this 70-yearold age sequence. Higher GPP and RE at the 20-year-old site, compared to the two older sites, were likely due to the additional effect of higher site quality due to greater water availability at this site (Peichl et al., 2010a). These results based on the mean values for NEP, GPP and RE from biometric and EC estimates agree with those from using estimates from only one of these two methods since their age-related patterns among sites are generally similar although their absolute values differ between 9 and $56 \%$. A detailed discussion on the underlying reasons for the deviation between the two methods was previously provided by Peichl et al. (2010c). Similar age patterns for forest production and respiration were reported for other forest age sequences (Goulden et al., 2011; Law et al., 2003; Luyssaert et al., 2007; Pregitzer and Euskirchen, 2004). However, in contrast to naturally regenerating forests, the switch from source to sink and the peak in NEP and NPP occurred about 10-20 years earlier in our afforested plantation stands, which highlights their potential for rapid $\mathrm{C}$ sequestration.

The contribution of DOC to NEP was considerable at the youngest site $(10 \%)$, while it was rather low $(<2 \%)$ at the three older sites. Previous work at these sites suggested that the reduced DOC export resulted from both a decrease in DOC concentrations at $1 \mathrm{~m}$ soil depth with increasing stand age as well as from decreased water leaching in the older stands compared to the youngest stand (Peichl et al., 2007). In agreement with our study, Kindler et al. (2011) found that DOC leaching hardly affected NEP at the majority of the forests investigated in their study. A decrease in soil solution leaching due to greater canopy interception and root water uptake and/or the increase in adsorption of DOC to soil particles due to accumulation of $\mathrm{Fe}$ and $\mathrm{Al}$ with stand age might explain the diminished DOC export in older forest stands (Camino-Serrano et al., 2014; Kothawala et al., 2009; Peichl et al., 2007). In contrast, a higher contribution of DOC of $11 \%$ was observed in a 80-year-old Belgian Scots pine stand (Gielen et al., 2011). Thus, depending on site productivity and hydrology, the relative contribution of the DOC export to the forest $\mathrm{C}$ balance might vary across forest ecosystems and become significant also at some of the mature forest sites.

The accumulated $\mathrm{C}$ sequestration simulated over the entire 70 years of the age sequence was substantial in both the high- and low-productivity scenarios. Moreover, the difference (by a factor of 2) due to site quality was considerable. The importance of site quality effects on forest growth is widely recognized in traditional forest research (McLeod and Running, 1988; Milner, 1992; Pietrzykowski, 2014; Vose and Allen, 1988) as well as in recent studies on the C allocation within forest stands (e.g. Vicca et al., 2012). Our study further highlights the need to account for differences in site quality when assessing forest C and GHG balances across forest ecosystems and to improve their up-scaling beyond ecosystem boundaries.

\subsection{Forest GHG balance across stand age and site productivity}

To date, few attempts have been made to quantify the total forest GHG balance and the relative contribution of individual components by including all relevant fluxes (i.e. $\mathrm{CO}_{2}$, $\mathrm{CH}_{4}, \mathrm{~N}_{2} \mathrm{O}$ and DOC) (Ball et al., 2007; Luyssaert et al., 2012; Schulze et al., 2009; Zona et al., 2013). Previous studies estimated GHG balances for individual forests at about $+3 \mathrm{t} \mathrm{CO}_{2}$ eq ha $^{-1}$ year $^{-1}$ for a young short-rotation poplar plantation (Zona et al., 2013) and approximately $-15 \mathrm{t} \mathrm{CO}_{2}$ eq ha ${ }^{-1}$ year $^{-1}$ for a middle-age pine forest (Ball et al., 2007), which is close to the range observed in our study. Both of these studies also agree with our findings of non$\mathrm{CO}_{2}$ GHGs contributing considerably to the GHG balance in recently established plantations (as well as in the mature 70-year-old forest in our study), whereas the $\mathrm{CO}_{2}$ exchange dominates the GHG balance in middle-aged forests. Using a process-based model, Inatomi et al. (2010) similarly found that the GHG balance was mainly driven by the $\mathrm{CO}_{2}$ exchange in a 50-year-old cool-temperate deciduous forest. However, the contribution of non- $\mathrm{CO}_{2}$ GHG could be substantial in poorly drained locations within temperate forests (Ullah and Moore, 2011). The relative contribution of $\mathrm{CH}_{4}$ and $\mathrm{N}_{2} \mathrm{O}$ to the forest GHG balance might further be considerably affected by more frequent freeze-thaw events (Luo et al., 2012; Teepe et al., 2001), altered $\mathrm{N}$ input (Liu and Greaver, 2009) as well as by contrasting forest management and tree growth responses to climatic changes in the future (Metsaranta et al., 2011; Ximenes et al., 2012). For instance, Metsaranta et al. (2011) suggested that the cumulative GWP over 70 years for a coniferous forest in British Columbia may vary between -67 and $67 \mathrm{t} \mathrm{CO}_{2}$ eq ha ${ }^{-1}$ in the bestand worst-case modelling scenario. Thus, the manifold variation in the magnitude of GWP and the relative contribution of non- $\mathrm{CO}_{2}$ gases to the GWP in these studies and among the four stands in our study emphasize that the forest GHG balance may vary widely within a heterogeneous (i.e. in terms of age and site quality) forest landscape, which needs to be considered when extrapolating findings from individual forest stands to regions.

Overall, our study advances the current understanding of the forest GHG balance by demonstrating that the magnitude and contribution of individual GHGs may have manifold variations in forests due to differences in stand age and site quality. Both factors determine the forest NEP and thus the magnitude of the $\mathrm{CO}_{2}$ flux, while in comparison having a relatively small effect on the $\mathrm{CH}_{4}, \mathrm{~N}_{2} \mathrm{O}$ and DOC fluxes. Thus, our findings suggest a link between NEP and the relative contribution of individual gases to the GHG balance, with the implication that the ecosystem exchange of $\mathrm{CO}_{2}$ is 
the dominant driver of the forest GHG balance partitioning. As a consequence, the contribution of $\mathrm{CH}_{4}, \mathrm{~N}_{2} \mathrm{O}$ and DOC fluxes to the GHG balance might be low in highly productive (e.g. middle-age) forests, whereas it may be more important in low-productivity (e.g. recently established and mature) forests due to the differences in NEP (as opposed to changes in the non- $\mathrm{CO}_{2}$ fluxes). Understanding the changes in individual contribution of forest $\mathrm{C}$ and $\mathrm{GHG}$ exchanges to the total GWP throughout their life cycle is imperative to evaluate the potential of these ecosystems as a tool in mitigating global warming and the increase of atmospheric GHG concentrations.

\section{Conclusions}

We combined $\mathrm{C}$ pools and fluxes of $\mathrm{CO}_{2}, \mathrm{CH}_{4}, \mathrm{~N}_{2} \mathrm{O}$ and DOC to estimate $\mathrm{C}$ and $\mathrm{GHG}$ balances for an age sequence (spanning 7-70 years) of afforested white pine stands in the temperate region of southern Ontario, Canada. Based on our findings we conclude that

- the magnitudes and within-stand partitioning of $\mathrm{CO}_{2}$ fluxes were highly variable with stand age and site quality;

- the role of DOC export for the $\mathrm{C}$ balance was substantial in the recently established pine plantation, but small to marginal in the highly productive maturing stands;

- the combined exchanges of $\mathrm{CH}_{4}$ and $\mathrm{N}_{2} \mathrm{O}$ significantly contributed to the GHG balance of the young and mature pine forests due to their lower NEP;

- stand age and site quality may cause manifold differences in the forest $\mathrm{C}$ and GHG balances and need to be accounted for to improve their up-scaling from ecosystems to regions;

- overall these temperate pine afforestation stands act as a substantial $\mathrm{C}$ sink and provide a considerable negative GWP throughout the maturing phase.

Acknowledgements. This study was funded by the Natural Sciences and Engineering Research Council (NSREC) Discovery and Strategic grants. Ontario Ministry of Environment (MOE), the Canadian Foundation of Innovation (CFI), the Ontario Innovation Trust (OIT) and McMaster University also provided funding. In-kind support from the Fluxnet-Canada Research Network (FCRN)/Canadian Carbon Program (CCP), the Canadian Foundation for Climate and Atmospheric Sciences (CFCAS), the Canadian Forest Service (CFS), the BIOCAP Foundation of Canada, the Ministry of Natural Resources Canada (MNR), the Ontario Ministry of Natural Resources (OMNR), the Long Point Recreation and Conservation Authority (LPRCA) and Ontario Power Generation (for providing tree seedlings at TP02) is also acknowledged. We thank Dolly Kothawala, Mike Dalva and
David Brodkey from McGill University for their help in field and laboratory work. We are grateful to Frank Bahula and Bruce Whitside and their families for providing access to their private forests (TP89 and TP02, respectively) to conduct this research.

Edited by: G. Wohlfahrt

\section{References}

Ågren, A., Buffam, I., Jansson, M., and Laudon, H.: Importance of seasonality and small streams for the landscape regulation of dissolved organic carbon export, J. Geophys. Res, 112, G03003, doi:10.1029/2006JG000381, 2007.

Arain, M. A. and Restrepo-Coupe, N.: Net ecosystem production in a temperate pine plantation in southeastern Canada, Agr. Forest Meteorol., 128, 223-241, 2005.

Ball, T., Smith, K. A., and Moncrieff, J. B.: Effect of stand age on greenhouse gas fluxes from a Sitka spruce [Picea sitchensis (Bong.) Carr.] chronosequence on a peaty gley soil, Glob. Change Biol., 13, 2128-2142, 2007.

Bárcena, T. G., Gundersen, P., and Vesterdal, L.: Afforestation effects on SOC in former cropland: oak and spruce chronosequences resampled after 13 years, Glob. Change Biol., 20, 29382952, 2014.

Bjarnadottir, B., Sigurdsson, B. D., and Lindroth, A.: A young afforestation area in Iceland was a moderate sink to $\mathrm{CO}_{2}$ only a decade after scarification and establishment, Biogeosciences, 6 , 2895-2906, doi:10.5194/bg-6-2895-2009, 2009.

Black, K., Bolger, T., Davis, P., Nieuwenhuis, M., Reidy, B., Saiz, G., Tobin, B. and Osborne, B.: Inventory and eddy covariancebased estimates of annual carbon sequestration in a Sitka spruce (Picea sitchensis (Bong.) Carr.) forest ecosystem, Europ. J. Forest Res., 126, 167-178, 2007.

Brown, S.: Measuring carbon in forests: current status and future challenges, Environmental Pollution, 116, 363-372, 2002.

Camino-Serrano, M., Gielen, B., Luyssaert, S., Ciais, P., Vicca, S., Guenet, B., Vos, B. D., Cools, N., Ahrens, B., Arain, A., Borken, W., Clarke, N., Clarkson, B., Cummins, T., Don, A., Pannatier, E. G., Laudon, H., Moore, T., Nieminen, T., Nilsson, M. B., Peichl, M., Schwendenmann, L., Siemens, J. and Janssens, I.: Linking variability in soil solution dissolved organic carbon to climate, soil type and vegetation type, Global Biogeochem. Cy., 28 , GB004726, doi:10.1002/2013GB004726, 2014.

Chen, J. M., Govind, A., Sonnentag, O., Zhang, Y., Barr, A., and Amiro, B.: Leaf area index measurements at Fluxnet-Canada forest sites, Agr. Forest Meteorol., 140, 257-268, 2006.

Christiansen, J. R. and Gundersen, P.: Stand age and tree species affect $\mathrm{N}_{2} \mathrm{O}$ and $\mathrm{CH}_{4}$ exchange from afforested soils, Biogeosciences, 8, 2535-2546, doi:10.5194/bg-8-2535-2011, 2011.

Christiansen, J. R., Vesterdal, L., and Gundersen, P.: Nitrous oxide and methane exchange in two small temperate forest catchments - effects of hydrological gradients and implications for global warming potentials of forest soils, Biogeochemistry, 107, 437454, 2012.

Coursolle, C., Margolis, H. A., Giasson, M.-A., Bernier, P.-Y., Amiro, B. D., Arain, M. A., Barr, A. G., Black, T. A., Goulden, M. L., McCaughey, J. H., Chen, J. M., Dunn, A. L., Grant, R. F., and Lafleur, P. M.: Influence of stand age on the magnitude 
and seasonality of carbon fluxes in Canadian forests, Agr. Forest Meteorol., 165, 136-148, 2012.

Dixon, R. K., Solomon, A. M., Brown, S., Houghton, R. A., Trexier, M. C., and Wisniewski, J.: Carbon pools and flux of global forest ecosystems, Science, 263, 185-190, 1994.

Don, A., Rebmann, C., Kolle, O., Scherer-Lorenzen, M., and Schulze, E.-D.: Impact of afforestation-associated management changes on the carbon balance of grassland, Glob. Change Biol., 15, 1990-2002, 2009.

Fernández-Martínez, M., Vicca, S., Janssens, I. A., Sardans, J., Luyssaert, S., Campioli, M., Chapin Iii, F. S., Ciais, P., Malhi, Y., Obersteiner, M., Papale, D., Piao, S. L., Reichstein, M., Rodà, F., and Peñuelas, J.: Nutrient availability as the key regulator of global forest carbon balance, Nat. Clim. Change, 4, 471-476, 2014.

Gielen, B., Neirynck, J., Luyssaert, S., and Janssens, I. A.: The importance of dissolved organic carbon fluxes for the carbon balance of a temperate Scots pine forest, Agr. Forest Meteorol., 151, 270-278, 2011.

Goodale, C. L., Apps, M. J., Birdsey, R. A., Field, C. B., Heath, L. S., Houghton, R. A., Jenkins, J. C., Kohlmaier, G. H., Kurz, W., Liu, S., Nabuurs, G.-J., Nilsson, S., and Shvidenko, A. Z.: Forest carbon sinks in the northern hemisphere, Ecol. Appl., 12, 891-899, 2002.

Goulden, M. L., Mcmillan, A. M. S., Winston, G. C., Rocha, A. V., Manies, K. L., Harden, J. W., and Bond-Lamberty, B. P.: Patterns of NPP, GPP, respiration, and NEP during boreal forest succession, Glob. Change Biol., 17, 855-871, 2011.

Gundersen, P., Christiansen, J. R., Alberti, G., Brüggemann, N., Castaldi, S., Gasche, R., Kitzler, B., Klemedtsson, L., Lobo-doVale, R., Moldan, F., Rütting, T., Schleppi, P., Weslien, P., and Zechmeister-Boltenstern, S.: The response of methane and nitrous oxide fluxes to forest change in Europe, Biogeosciences, 9, 3999-4012, doi:10.5194/bg-9-3999-2012, 2012.

Hiltbrunner, D., Zimmermann, S., Karbin, S., Hagedorn, F., and Niklaus, P. A.: Increasing soil methane sink along a 120-year afforestation chronosequence is driven by soil moisture, Glob. Change Biol., 18, 3664-3671, 2012.

Houghton, R. A., Davidson, E. A., and Woodwell, G. M.: Missing sinks, feedbacks, and understanding the role of terrestrial ecosystems in the global carbon balance, Global Biogeochem. Cy., 12, 25-34, 1998.

Inatomi, M., Ito, A., Ishijima, K., and Murayama, S.: Greenhouse gas budget of a cool-temperate deciduous broad-leaved forest in Japan estimated using a process-based model, Ecosystems, 13, 472-483, 2010.

IPCC: The Physical Science Basis. Contribution of Working Group I to the Fifth Assessment Report of the Intergovernmental Panel on Climate Change, edited by: Stocker, T. F., Qin, D., Plattner, G.-K., Tignor, M., Allen, S. K., Boschung, J., Nauels, A., Xia, Y., Bex, V., and Midgley, P. M., Cambridge University Press, Cambridge, 2013.

Khomik, M., Arain, M. A., and McCaughey, J. H.: Temporal and spatial variability of soil respiration in a boreal mixedwood forest, Agr. Forest Meteorol., 140, 244-256, 2006.

Khomik, M., Arain, M. A., Liaw, K.-L., and McCaughey, J. H.: Debut of a flexible model for simulating soil respiration-soil temperature relationship: Gamma model, J. Geophys. Res., 114, G03004, doi:10.1029/2009JG001089, 2009.
Khomik, M., Arain, M. A., Brodeur, J. J., Peichl, M., RestrepoCoupé, N., and McLaren, J. D.: Relative contributions of soil, foliar, and woody tissue respiration to total ecosystem respiration in four pine forests of different ages, J. Geophys. Res., 115, G03024, doi:10.1029/2009JG001089, 2010.

Kindler, R., Siemens, J., Kaiser, K., Walmsley, D. C., Bernhofer, C., Buchmann, N., Cellier, P., Eugster, W., Gleixner, G., GrũNwald, T., Heim, A., Ibrom, A., Jones, S. K., Jones, M., Klumpp, K., Kutsch, W., Larsen, K. S., Lehuger, S., Loubet, B., Mckenzie, R., Moors, E., Osborne, B., Pilegaard, K., Rebmann, C., Saunders, M., Schmidt, M. W. I., Schrumpf, M., Seyfferth, J., Skiba, U., Soussana, J.-F., Sutton, M. A., Tefs, C., Vowinckel, B., Zeeman, M. J., and Kaupenjohann, M.: Dissolved carbon leaching from soil is a crucial component of the net ecosystem carbon balance, Glob. Change Biol., 17, 1167-1185, 2011.

Kothawala, D. N., Moore, T. R., and Hendershot, W. H.: Soil properties controlling the adsorption of dissolved organic carbon to mineral soils, Soil Sci. Soc. Am. J., 73, 1831-1842, 2009.

Law, B. E., Thornton, P. E., Irvine, J., Anthoni, P. M., and Van Tuyl, S.: Carbon storage and fluxes in ponderosa pine forests at different developmental stages, Glob. Change Biol., 7, 755-777, 2001.

Law, B. E., Sun, O. J., Campbell, J., Van Tuyl, S., and Thornton, P. E.: Changes in carbon storage and fluxes in a chronosequence of ponderosa pine, Glob. Change Biol., 9, 510-524, 2003.

Liu, L. and Greaver, T. L.: A review of nitrogen enrichment effects on three biogenic GHGs: the $\mathrm{CO}_{2}$ sink may be largely offset by stimulated $\mathrm{N}_{2} \mathrm{O}$ and $\mathrm{CH}_{4}$ emission, Ecol. Lett., 12, 1103-1117, 2009.

Luo, G. J., Brüggemann, N., Wolf, B., Gasche, R., Grote, R., and Butterbach-Bahl, K.: Decadal variability of soil $\mathrm{CO}_{2}, \mathrm{NO}$, $\mathrm{N}_{2} \mathrm{O}$, and $\mathrm{CH}_{4}$ fluxes at the Höglwald Forest, Germany, Biogeosciences, 9, 1741-1763, doi:10.5194/bg-9-1741-2012, 2012.

Luyssaert, S., Inglima, I., Jung, M., Richardson, a. D., Reichstein, M., Papale, D., Piao, S. L., Schulze, E. -d, Wingate, L., Matteucci, G., Aragao, L., Aubinet, M., Beer, C., Bernhofer, C., Black, K. G., Bonal, D., Bonnefond, J. -m, Chambers, J., Ciais, P., Cook, B., Davis, K. J., Dolman, a. J., Gielen, B., Goulden, M., Grace, J., Granier, A., Grelle, A., Griffis, T., Grünwald, T., Guidolotti, G., Hanson, P. J., Harding, R., Hollinger, D. Y., Hutyra, L. R., Kolari, P., Kruijt, B., Kutsch, W., Lagergren, F., Laurila, T., Law, B. E., Le Maire, G., Lindroth, A., Loustau, D., Malhi, Y., Mateus, J., Migliavacca, M., Misson, L., Montagnani, L., Moncrieff, J., Moors, E., Munger, J. W., Nikinmaa, E., Ollinger, S. V., Pita, G., Rebmann, C., Roupsard, O., Saigusa, N., Sanz, M. J., Seufert, G., Sierra, C., Smith, M. -1, Tang, J., Valentini, R., Vesala, T., and Janssens, I. A.: $\mathrm{CO}_{2}$ balance of boreal, temperate, and tropical forests derived from a global database, Glob. Change Biol., 13, 2509-2537, 2007.

Luyssaert, S., Ciais, P., Piao, S. L., Schulze, E.-D., Jung, M., Zaehle, S., Schelhaas, M. J., Reichstein, M., Churkina, G., Papale, D., Abril, G., Beer, C., Grace, J., Loustau, D., Matteucci, G., Magnani, F., Nabuurs, G. J., Verbeeck, H., Sulkava, M., Van Der WERF, G. R., Janssens, I. A., and Team, members of the C.-I. S.: The European carbon balance, Part 3: forests, Glob. Change Biol., 16, 1429-1450, 2010.

Luyssaert, S., Abril, G., Andres, R., Bastviken, D., Bellassen, V., Bergamaschi, P., Bousquet, P., Chevallier, F., Ciais, P., Corazza, M., Dechow, R., Erb, K.-H., Etiope, G., Fortems-Cheiney, A., Grassi, G., Hartmann, J., Jung, M., Lathière, J., Lohila, A., May- 
orga, E., Moosdorf, N., Njakou, D. S., Otto, J., Papale, D., Peters, W., Peylin, P., Raymond, P., Rödenbeck, C., Saarnio, S., Schulze, E.-D., Szopa, S., Thompson, R., Verkerk, P. J., Vuichard, N., Wang, R., Wattenbach, M., and Zaehle, S.: The European land and inland water $\mathrm{CO}_{2}, \mathrm{CO}, \mathrm{CH}_{4}$ and $\mathrm{N}_{2} \mathrm{O}$ balance between 2001 and 2005, Biogeosciences, 9, 3357-3380, doi:10.5194/bg9-3357-2012, 2012.

McLaren, J. D., Arain, M. A., Khomik, M., Peichl, M., and Brodeur, J.: Water flux components and soil water-atmospheric controls in a temperate pine forest growing in a well-drained sandy soil, J. Geophys. Res., 113, G04031, doi:10.1029/2007JG000653, 2008.

McLeod, S. D. and Running, S. W.: Comparing site quality indices and productivity in ponderosa pine stands of western Montana, Can. J. For. Res., 18, 346-352, 1988.

Metsaranta, J. M., Dymond, C. C., Kurz, W. A., and Spittlehouse, D. L.: Uncertainty of 21 st century growing stocks and GHG balance of forests in British Columbia, Canada resulting from potential climate change impacts on ecosystem processes, Forest Ecol. Manag., 262, 827-837, 2011.

Milner, K. S.: Site index and height growth curves for ponderosa pine, Western larch, lodgepole pine, and Douglas-fir in Western Montana, Western J. Appl. Forest., 7, 9-14, 1992.

Montzka, S. A., Dlugokencky, E. J., and Butler, J. H.: Non- $\mathrm{CO}_{2}$ greenhouse gases and climate change, Nature, 476, 43-50, 2011.

Moore, T. R., de Souza, W., and Koprivnjak, J.-F.: Controls on the sorption of dissolved organic carbon by soils, Soil Sci., 154, 120 129, 1992.

Moore, T. R., Trofymow, J. A., Taylor, B., Prescott, C., Camiré, C., Duschene, L., Fyles, J., Kozak, L., Kranabetter, M., Morrison, I., Siltanen, M., Smith, S., Titus, B., Visser, S., Wein, R., and Zoltai, S.: Litter decomposition rates in Canadian forests, Glob. Change Biol., 5, 75-82, 1999.

Nabuurs, G. J., Masera, O., Andrasko, K., Benitez-Ponce, P., Boer, R., Dutschke, M., Elsiddig, E., Ford-Robertson, J., Frumhoff, P., Karjalainen, T., Krankina, O., Kurz, W. A., Matsumoto, M., Oyhantcabal, W., Ravindranath, N. H., Sanz Sanchez, M. J., and Zhang, X.: Forestry, in: Climate Change 2007: Mitigation, Contribution of Working Group III to the Fourth Assessment Report of the Intergovernmental Panel on Climate Change, edited by: Metz, B., Davidson, O. R., Bosch, P. R., Dave, R., Meyer, L. A., 541-584, 2007.

NFI: National forest inventory. NFI ground sampling guidelines, Working draft v.4.0, 87 pp., 2003.

Niu, X. and Duiker, S. W.: Carbon sequestration potential by afforestation of marginal agricultural land in the Midwestern US, Forest Ecol. Manag., 223, 415-427, 2006.

Pan, Y., Birdsey, R. A., Fang, J., Houghton, R., Kauppi, P. E., Kurz, W. A., Phillips, O. L., Shvidenko, A., Lewis, S. L., Canadell, J. G., Ciais, P., Jackson, R. B., Pacala, S. W., McGuire, A. D., Piao, S., Rautiainen, A., Sitch, S., and Hayes, D.: A large and persistent carbon sink in the world's forests, Science, 333, 988-993, 2011.

Peichl, M. and Arain, M. A.: Above- and belowground ecosystem biomass and carbon pools in an age-sequence of temperate pine plantation forests, Agr. Forest Meteorol., 140, 51-63, 2006.

Peichl, M. and Arain, M. A.: Allometry and partitioning of aboveand belowground tree biomass in an age-sequence of white pine forests, Forest Ecol. Manag., 253, 68-80, 2007.

Peichl, M., Moore, T. R., Arain, M. A., Dalva, M., Brodkey, D., and McLaren, J.: Concentrations and fluxes of dissolved organic car- bon in an age-sequence of white pine forests in Southern Ontario, Canada, Biogeochemistry, 86, 1-17, 2007.

Peichl, M., Arain, M. A., and Brodeur, J. J.: Age effects on carbon fluxes in temperate pine forests, Agr. Forest Meteorol., 150, 1090-1101, 2010a.

Peichl, M., Arain, M. A., Ullah, S., and Moore, T. R.: Carbon dioxide, methane, and nitrous oxide exchanges in an age-sequence of temperate pine forests, Glob. Change Biol., 16, 2198-2212, 2010b.

Peichl, M., Brodeur, J. J., Khomik, M., and Arain, M. A.: Biometric and eddy-covariance based estimates of carbon fluxes in an agesequence of temperate pine forests, Agr. Forest Meteorol., 150, 952-965, 2010c

Pietrzykowski, M.: Soil quality index as a tool for Scots pine (Pinus sylvestris) monoculture conversion planning on afforested, reclaimed mine land, J. Forest. Res., 25, 63-74, 2014.

Pregitzer, K. S. and Euskirchen, E. S.: Carbon cycling and storage in world forests: biome patterns related to forest age, Glob. Change Biol., 10, 2052-2077, 2004.

Priemé, A., Christensen, S., Dobbie, K. E., and Smith, K. A.: Slow increase in rate of methane oxidation in soils with time following land use change from arable agriculture to woodland, Soil Biol. Biochem., 29, 1269-1273, 1997.

Reich, P. B.: Taking stock of forest carbon, Nat. Clim. Change, 1, 346-347, 2011.

Rosenqvist, L., Kleja, D. B., and Johansson, M.-B.: Concentrations and fluxes of dissolved organic carbon and nitrogen in a Picea abies chronosequence on former arable land in Sweden, Forest Ecol. Manag., 259, 275-285, 2010.

Schimel, D. S.: Terrestrial ecosystems and the carbon cycle, Glob. Change Biol., 1, 77-91, 1995.

Schulze, E. D., Luyssaert, S., Ciais, P., Freibauer, A., and Janssens et al., I. A.: Importance of methane and nitrous oxide for $\mathrm{Eu}-$ rope's terrestrial greenhouse-gas balance, Nature Geosci., 2, 842-850, 2009.

Schulze, E. D., Ciais, P., Luyssaert, S., Schrumpf, M., Janssens, I. A., Thiruchittampalam, B., Theloke, J., Saurat, M., Bringezu, S., Lelieveld, J., Lohila, A., Rebmann, C., Jung, M., Bastviken, D., Abril, G., Grassi, G., Leip, A., Freibauer, A., Kutsch, W., Don, A., Nieschulze, J., Börner, A., Gash, J. H., and Dolman, A. J.: The European carbon balance. Part 4: integration of carbon and other trace-gas fluxes, Glob. Change Biol., 16, 1451-1469, 2010.

Smith, K. A., Ball, T., Conen, F., Dobbie, K. E., Massheder, J., and Rey, A.: Exchange of greenhouse gases between soil and atmosphere: interactions of soil physical factors and biological processes, Europ. J. Soil Sci., 54, 779-791, 2003.

Smith, P., Martino, D., Cai, Z., Gwary, D., Janzen, H., Kumar, P., McCarl, B., Ogle, S., O’Mara, F., Rice, C., Scholes, B., Sirotenko, O., Howden, M., McAllister, T., Pan, G., Romanenkov, V., Schneider, U., Towprayoon, S., Wattenbach, M., and Smith, J.: Greenhouse gas mitigation in agriculture, Philos. Trans. R Soc. Lond. B Biol. Sci., 363, 789-813, 2008.

Teepe, R., Brumme, R., and Beese, F.: Nitrous oxide emissions from soil during freezing and thawing periods, Soil Biol. Biochem., 33, 1269-1275, 2001.

Tian, H., Xu, X., Liu, M., Ren, W., Zhang, C., Chen, G., and Lu, C.: Spatial and temporal patterns of $\mathrm{CH} 4$ and $\mathrm{N}_{2} \mathrm{O}$ fluxes in terrestrial ecosystems of North America during 1979-2008: appli- 
cation of a global biogeochemistry model, Biogeosciences, 7, 2673-2694, doi:10.5194/bg-7-2673-2010, 2010.

Trofymow, J. A., Moore, T. R., Titus, B., Prescott, C., Morrison, I., Siltanen, M., Smith, S., Fyles, J., Wein, R., Camiré, C., Duschene, L., Kozak, L., Kranabetter, M., and Visser, S.: Rates of litter decomposition over 6 years in Canadian forests: influence of litter quality and climate, Can. J. For. Res., 32, 789-804, 2002.

Ullah, S. and Moore, T. R.: Biogeochemical controls on methane, nitrous oxide, and carbon dioxide fluxes from deciduous forest soils in eastern Canada, J. Geophys. Res., 116, G03010, doi:10.1029/2010JG001525, 2011.

Van Bochove, E., Jones, H. G., Bertrand, N., and Prévost, D.: Winter fluxes of greenhouse gases from snow-covered agricultural soil:intra-annual and interannual variations, Global Biogeochem. Cy., 14, 113-125, 2000.

Vanninen, P., Ylitalo, H., Sievänen, R., and Mäkelä, A.: Effects of age and site quality on the distribution of biomass in Scots pine (Pinus sylvestris L.), Trees, 10, 231-238, 1996.

Van Wagner, C. E.: The line intersect method in forest fuel sampling, For. Sci., 14, 20-26, 1968.

Vicca, S., Luyssaert, S., Peñuelas, J., Campioli, M., Chapin, F. S., Ciais, P., Heinemeyer, A., Högberg, P., Kutsch, W. L., Law, B. E., Malhi, Y., Papale, D., Piao, S. L., Reichstein, M., Schulze, E. D., and Janssens, I. A.: Fertile forests produce biomass more efficiently, Ecol. Lett., 15, 520-526, 2012.
Vose, J. M. and Allen, H. L.: Leaf area, stemwood growth, and nutrition relationships in loblolly pine, Forest Sci., 34, 547-563, 1988.

Waring, R. H., Landsberg, J. J., and Williams, M.: Net primary production of forests: A constant fraction of gross primary production?, Tree Physiology, 18, 129-134, 1998.

Ximenes, F. de A., George, B. H., Cowie, A., Williams, J., and Kelly, G.: Greenhouse gas balance of native forests in New South Wales, Australia, Forests, 3, 653-683, 2012.

Yang, Y., Luo, Y., and Finzi, A. C.: Carbon and nitrogen dynamics during forest stand development: a global synthesis, New Phytologist, 190, 977-989, 2011.

Yashiro, Y., Mariko, S., and Koizumi, H.: Emission of nitrous oxide through a snowpack in ten types of temperate ecosystems in Japan, Ecol. Res., 21, 776-781, 2006.

Zona, D., Janssens, I. A., Aubinet, M., Gioli, B., Vicca, S., Fichot, R., and Ceulemans, R.: Fluxes of the greenhouse gases $\left(\mathrm{CO}_{2}\right.$, $\mathrm{CH}_{4}$ and $\mathrm{N}_{2} \mathrm{O}$ ) above a short-rotation poplar plantation after conversion from agricultural land, Agr. Forest Meteorol., 169, 100110, 2013. 